\title{
Editorial: T Cell Alterations in Adipose Tissue During Obesity, HIV, and Cancer
}

\author{
Dorothy E. Lewis ${ }^{1 *}$, Joanne Lysaght ${ }^{2}$ and Huaizhu $W u^{3}$ \\ ${ }^{1}$ McGovern Medical School, The University of Texas Health Science Center, Houston, TX, United States, ${ }^{2}$ Department of \\ Surgery, Trinity Translational Medicine Institute St. James's Hospital, Dublin, Ireland, ${ }^{3}$ Section of Cardiovascular Research, \\ Department of Medicine, Baylor College of Medicine, Houston, TX, United States
}

Keywords: T cells, obesity, cancer, HIV, inflammation

\section{Editorial on the Research Topic}

\section{T Cell Alterations in Adipose Tissue during Obesity, HIV and Cancer}

This collection of articles is designed to foster understanding of the variety and function of $\mathrm{T}$ cells in adipose from different species in different disease states. This work originally developed from the obesity epidemic. As the obesity epidemic grew, initial work recognized that adipose was dysfunctional. Work focused on inflammatory macrophages that increase in adipose during over-nutrition to produce inflammatory cytokines (1-3), which also serve to increase the

\section{OPEN ACCESS}

Edited by:

Remy Bosselut,

National Cancer Institute (NCl),

United States

Reviewed by:

Valerie Dardalhon,

UMR5535 Institut de Génétique Moléculaire de Montpellier

(IGMM), France

*Correspondence:

Dorothy E. Lewis

Dorothy.e.lewis@uth.tmc.edu

Specialty section:

This article was submitted to

T Cell Biology,

a section of the journal

Frontiers in Immunology

Received: 15 March 2019

Accepted: 10 May 2019

Published: 28 May 2019

Citation:

Lewis DE, Lysaght J and Wu H (2019)

Editorial: $T$ Cell Alterations in Adipose

Tissue During Obesity, HIV, and

Cancer. Front. Immunol. 10:1190.

doi: 10.3389/fimmu.2019.01190 dysfunction of adipose. However, it was soon realized especially in mouse studies that $\mathrm{T}$ cells had an increased role, specifically that obesity was associated with an increase in Th1 and Th17 T cells that make inflammatory cytokines (4-9), which also drive adipose dysfunction $(4,10,11)$. Recent studies suggest that obesity in cancer patients may be a major risk factor for acquisition LaubySecretan et al. (12) but a positive feature in response to certain therapies for certain tumors Wang et al. (13). Because there is widespread adipose dysfunction in HIV infected people, there was also focus on how and why adipose changed, whether it was in response to antiretroviral therapy or due to infection itself $(14,15)$. This collection of articles are mainly reviews which cover what is known about T cells in obesity, in cancer, and in HIV.

Two articles Wang and Wu, Zhou and Liu and examine the role of T cells in metabolism as well as the interactions with antigen presenting cells in adipose. The review by Wang integrates what we know about $\mathrm{T}$ cells and macrophages in adipose and how they function and differ in obesity vs. the lean state. The Liu review nicely shows what happens after over feeding as the cells and resulting molecular consequences in adipose tissue changes. There is an initial response by adipocytes in the first days, followed by induction of pro-inflammatory cytokines and recruitment of T cells and macrophages in the first 2-3 weeks, followed by reduction in Foxp3 at 12 weeks in the mouse. How this develops in humans is not clear, although constant high fat feeding takes very little time to cause major changes in appearance and lipid and liver enzymes as seen in the movie, Super Size Me released in 2004. In the movie, Morgan Spurlock ate only at McDonald's for a month. He gained 11 lbs that took him 14 months to lose.

Another article examines how and why the $\mathrm{T}$ cells in aging animals, which are also usually obese, might be different than those found in young obese animals Antony et al. In particular, the differences seem to lie in differences in $\mathrm{T}$ reg numbers or function in aging. In particular the numbers of $\mathrm{T}$ regs increase in aging and their function changes perhaps as a response to the prolonged lipophilic environment found in aging mice. Work on human adipose in aging remains to be done, but from mouse studies it is clear that the changes in adipose are different in aging than in mere obesity. 
Two articles focus on the role of $\mathrm{T}$ regs in regulation of metabolism in obesity and in different species. The review by Zeng et al. covers what is known about the function of $\mathrm{T}$ regs in adipose in humans and mice, noting that several studies in humans associated Foxp3 expression with obesity. However, measuring $\mathrm{T}$ regs by flow cytometry has produced inconsistent results. There is some concern that variations might be due to fresh vs. frozen tissue observations, since $\mathrm{T}$ reg staining is reduced by freezing in some cases. In addition, human CD4 T cells express Foxp3 when they are activated, it is normally transient, therefore results of Foxp 3 mRNA studies are confounded by that caveat. Cold also induces $\mathrm{T}$ regs in mouse adipose, but it is unknown if the same is true in humans. Finally, the authors present a nice summary of attempts to exploit $\mathrm{T}$ regs for obesity therapy. A comparison of adipose from different species (humans, mice, and cynomolgus monkeys) was done by Laparra et al. which clearly indicates that most animals except for the C57 mouse do NOT have increased Foxp3 T cells in the lean state. Adipocyte size is also markedly different between the three species. The dramatic conclusion is that mouse and human adipose tissue have markedly different immune cell compositions which should offer caution when interpreting mouse studies. More studies need to be done on young humans and on feral mouse populations to know whether environmental differences could contribute to these differences.

Two articles concern characteristics of $\mathrm{T}$ cells in cancer patients. One (Cornò) examines the information about innate lymphocytes in adipose and how they differ in obesity, as these cells likely act as sentinels to control tumor development Del Corno et al. Most of the work has been done in the peripheral blood and indicates that there is a decrease in many innate lymphocytes in the blood in obesity. In adipose there is some evidence for a decrease but more work is needed to directly

\section{REFERENCES}

1. Weisberg SP, McCann D, Desai M, Rosenbaum M, Leibel RL, Ferrante AW Jr. Obesity is associated with macrophage accumulation in adipose tissue. J Clin Invest. (2003) 112:1796-808. doi: 10.1172/JCI 19246

2. Xu H, Barnes GT, Yang Q, Tan G, Yang D, Chou CJ, et al. Chronic inflammation in fat plays a crucial role in the development of obesityrelated insulin resistance. J Clin Invest. (2003) 112:1821-30. doi: 10.1172/JCI 19451

3. Lumeng CN, Bodzin JL, Saltiel AR. Obesity induces a phenotypic switch in adipose tissue macrophage polarization. J Clin Invest. (2007) 117:175-84. doi: 10.1172/JCI29881

4. Wu H, Ghosh S, Perrard XD, Feng L, Garcia GE, Perrard JL, et al. Tcell accumulation and regulated on activation, normal $\mathrm{T}$ cell expressed and secreted upregulation in adipose tissue in obesity. Circulation. (2007) 115:1029-38. doi: 10.1161/CIRCULATIONAHA.106.638379

5. Feuerer M, Herrero L, Cipolletta D, Naaz A, Wong J, Nayer A, et al. Lean, but not obese, fat is enriched for a unique population of regulatory $\mathrm{T}$ cells that affect metabolic parameters. Nat Med. (2009) 15:930-9. doi: 10.1038/ nm.2002

6. Nishimura S, Manabe I, Nagasaki M, Eto K, Yamashita H, Ohsugi $\mathrm{M}$, et al. CD8+ effector $\mathrm{T}$ cells contribute to macrophage recruitment and adipose tissue inflammation in obesity. Nat Med. (2009) 15:914-20. doi: $10.1038 / \mathrm{nm} .1964$ link these cells to development of cancer. Another paper Conroy et al. reports novel data for the chemokine fractalkine found in omentum as well as its receptor (CX3CR1) in cancer patients and links it to memory CD8 $\mathrm{T}$ cell recruitment to the omentum perhaps bypassing the tumor and leading to a mechanism whereby tumor cells are allowed to go unchecked.

A single article reviews human $\mathrm{T}$ cells found in HIV and compares the information to the $\mathrm{T}$ cell changes in obesity Wanjalla et al. A key difference in HIV is that there are clonal populations of CD8 $\mathrm{T}$ cells and those cells predominate with reduced $\mathrm{CD} 4 \mathrm{~T}$ cells. In obesity, although $\mathrm{CD} 8 \mathrm{~T}$ cells have greater increases in adipose compared to lean $(6,16)$ there are higher levels of polyclonal memory CD4 T cells than CD8 T cells (16). In addition, in HIV there are fewer Tregs, with more in obese humans. Finally a key recent observation is that CD4 T cells in human adipose express more PD-1 which has implications for adipose as a reservoir for HIV.

In summary, this collection of articles provide the background to focus efforts on preventing the consequences of adipose dysfunction seen in so many disease states.

\section{AUTHOR CONTRIBUTIONS}

All authors listed have made a substantial, direct and intellectual contribution to the work, and approved it for publication.

\section{ACKNOWLEDGMENTS}

Thanks to all those who submitted articles and to Pamela Love for edits. HW is supported by an National Institutes of Health grant (R01 HL098839), American Heart Association award (AHA16GRNT30410012), and American Diabetes Association award (1-17-IBS-082).
7. Winer S, Chan Y, Paltser G, Truong D, Tsui H, Bahrami J, et al. Normalization of obesity-associated insulin resistance through immunotherapy. Nat Med. (2009) 15:921-9. doi: 10.1038/nm.2001

8. Bertola A, Ciucci T, Rousseau D, Bourlier V, Duffaut C, Bonnafous S, et al. Identification of adipose tissue dendritic cells correlated with obesityassociated insulin-resistance and inducing Th17 responses in mice and patients. Diabetes. (2012) 61:2238-47. doi: 10.2337/db11-1274

9. Deng T, Lyon CJ, Minze LJ, Lin J, Zou J, Liu JZ, et al. Class II major histocompatibility complex plays an essential role in obesity-induced adipose inflammation. Cell Metab. (2013) 17:411-22. doi: 10.1016/j.cmet.2013. 02.009

10. Khan IM, Dai Perrard XY, Perrard JL, Mansoori A, Smith CW, Wu H, et al. Attenuated adipose tissue and skeletal muscle inflammation in obese mice with combined CD4+ and CD8+ T cell deficiency. Atherosclerosis. (2014) 233:419-28. doi: 10.1016/j.atherosclerosis.2014.01.011

11. Khan IM, Perrard XY, Brunner G, Lui H, Sparks LM, Smith SR, et al. Intermuscular and perimuscular fat expansion in obesity correlates with skeletal muscle $\mathrm{T}$ cell and macrophage infiltration and insulin resistance. Int $J$ Obes. (2015) 39:1607-18. doi: 10.1038/ijo.2015.104

12. Lauby-Secretan B, Scoccianti C, Loomis D, Grosse Y, Bianchini F, Straif K, et al. Body fatness and cancer-viewpoint of the IARC working group. $N$ Engl J Med. (2016) 375:794-8. doi: 10.1056/NEJMsr1606602

13. Caron-Debarle M, Lagathu C, Boccara F, Vigouroux C, Capeau J. HIVassociated lipodystrophy: from fat injury to premature aging. Trends Mol Med. (2010) 16:218-29. doi: 10.1016/j.molmed.2010.03.002 
14. Wang Z, Aguilar EG, Luna JI, Dunai C, Khuat LT, Le CT, et al. Paradoxical effects of obesity on $\mathrm{T}$ cell function during tumor progression and PD-1 checkpointblockade. Nat Med. (2019) 25:141-51. doi: 10.1038/s41591-018-0221-5

15. Couturier J, Lewis DE. HIV persistence in adipose tissue reservoirs. Curr HIV/AIDS Rep. (2018) 15:60-71. doi: 10.1007/s11904-018-0378-z

16. Jiang E, Perrard XD, Yang D, Khan IM, Perrard JL, Smith CW, et al. Essential role of CD11a in CD8 + T-cell accumulation and activation in adipose tissue. Arterioscler Thromb Vasc Biol. (2014) 34:34-43. doi: 10.1161/ATVBAHA.113.302077
Conflict of Interest Statement: The authors declare that the research was conducted in the absence of any commercial or financial relationships that could be construed as a potential conflict of interest.

Copyright (c) 2019 Lewis, Lysaght and Wu. This is an open-access article distributed under the terms of the Creative Commons Attribution License (CC BY). The use, distribution or reproduction in other forums is permitted, provided the original author(s) and the copyright owner(s) are credited and that the original publication in this journal is cited, in accordance with accepted academic practice. No use, distribution or reproduction is permitted which does not comply with these terms. 